\title{
APLIKASI KELAYAKAN LAHAN TANAM SINGKONG BERDASARKAN HASIL PANEN BERBASIS MOBILE
}

\author{
Dedi Darwis \\ Manajemen Informatika, AMIK Teknokrat, \\ Jl.ZA Pagaralam, No 9-11, Kedaton, Bandarlampung, Indonesia \\ Email :darwisdedi@teknokrat.ac.id
}

\begin{abstract}
Abstrak
Informasi tentang kelayakan lahan tanam singkong khususnya di Provinsi Lampung sangat diperlukan karena berdasarkan data yang didapat pada dinas pertanian provinsi lampung, wilayah ini merupakan tanah yang tergolong subur, akan tetapi para masyarakat dan calon investor pertanian seringkali mengalami kesulitan dalam membutuhkan informasi tentang kabupaten atau kecamatan mana yang layak ditanami singkong berdasarkan hasil panen sebelumnya.Penelitian ini membahas bagaimana penerapan sistem informasi geografis berbasis android mobile, karena aplikasi berbasis mobile pada saat ini adalah yang paling sering digunakan oleh kebanyakan masyarakat modern. Hasil dari penelitian ini adalah memudahkan para masyarakat khususnya provinsi lampung dan para investor di bidang pertanian dalam mencari lokasi yang layak ditanami singkong agar mendapatkan hasil panen yang maksimal.
\end{abstract}

Kata Kunci :Sistem Informasi Geografis, Mobile Computing, Android, Hasil Panen Singkong

\section{Pendahuluan}

Saat ini informasi sudah menjadi suatu kebutuhan yang sangat penting bagi setiap orang. Seiring dengan perkembangan akan kecanggihan teknologi informasi dan tingkat pendidikan masyarakat yang semakin tinggi, mendorong kita untuk menggunakan internet sebagai sarana penyedia informasi yang cepat dan tepat. Informasi yang dibutuhkan masyarakat Lampung pada saat ini adalah kebutuhan informasi tentang pertanian karena sebagian masyarakat Provinsi Lampung adalah petani.Pengetahuan di bidang pertanian sangat perlu dikembangkan dalam teknologi modern.Teknologi SIG (Sistem Informasi Geografis) atau Georaphic Information System (GIS) merupakan suatu teknologi mengenai geografis yang memiliki kemampuan dalam menggambarkan data spasial berikut atribut-atributnya, seperti memodifikasi bentuk, warna, ukuran, dan symbol dalam peta.Provinsi Lampung memiliki berbagai informasi geografis yang berhubungan dengan lokasi lahan pertaniankhususnya tanaman singkong, seperti informasi lahan dan lokasi suatu daerah, lahan pertanian, tempat-tempat kios pupuk, tempat irigasi dan tempat pembibitan singkong.Informasi tersebut dibutuhkan oleh berbagai pihak dengan berbagai keperluannya masingmasing. Ruang lingkup dari penelitian ini adalah menyediakan informasi letak kesesuaian lahan tanam yang baik untuk tanaman singkong dan pengujian kelayakan lahan tanam singkong di provinsi Lampung dengan tujuan : Mempermudah calon investor dalam memperoleh informasi letak lahan pertanian singkong di Provinsi Lampung, Menyampaikan informasi tentang lahan yang baik berdasarkan produktivitas hasil panen untuk kesesuain lahan singkong berdasarkan peta georafis Lampung.

\section{Landasan Teori}

\section{A. Sistem Informasi Geografis}

sistem informasi khusus yang mengelola data yang memiliki informasi spasial (bereferensi keruangan). Atau dalam arti yang lebih sempit, adalah sistem komputer yang memiliki kemampuan untuk membangun, menyimpan, mengelola dan menampilkan informasi berefrensi geografis, misalnya data yang diidentifikasi menurut lokasinya, dalam sebuah database.Teknologi Sistem Informasi Geografis dapat digunakan untuk investigasi ilmiah, pengelolaan sumber daya, perencanaan pembangunan, kartografi dan perencanaan rute. Misalnya, SIG bisa membantu perencana untuk secara cepat menghitung waktu tanggap darurat saat terjadi bencana alam, atau SIG dapat digunaan untuk mencari lahan basah (wetlands) yang membutuhkan perlindungan dari polusi[3].

\section{B. Komponen Sistem Informasi Geografis}

Komponen-komponen pendukung SIG terdiri dari lima komponen yang bekerja secara terintegrasi yaitu perangkat keras (hardware), perangkat lunak (software), data, manusia, dan metode yang dapat diuraikan sebagai berikut: [4]

\section{Perangkat Keras (Hardware)}

Perangkat keras SIG adalah perangkat-perangkat fisik yang merupakan bagian dari sistem komputer yang mendukung analisis goegrafi dan pemetaan.Perangkat keras SIG mempunyai kemampuan untuk menyajikan citra dengan resolusi dan kecepatan yang tinggi serta mendukung operasioperasi basis data dengan volume data yang besar secara cepat.Perangkat keras SIG terdiri dari beberapa bagian untuk menginput data, mengolah data, dan mencetak hasil proses. Berikut ini pembagian berdasarkan proses : Input data: mouse, digitizer, scanner; Olah data: harddisk, processor, RAM, VGA Card; Output data: plotter, printer, screening.

\section{Perangkat Lunak (Software)}

Perangkat lunak digunakan untuk melakukan proses menyimpan, menganalisa, memvisualkan data-data baik data spasial maupun non-spasial. Perangkat lunak yang 
harus terdapat dalam komponen software SIG adalah : Alat untuk memasukkan dan memanipulasi data SIG; Data Base Management System (DBMS); Alat untuk menganalisa data-data; Alat untuk menampilkan data dan hasil analisa.

\section{Data}

Pada prinsipnya terdapat dua jenis data untuk mendukung SIG yaitu : Data Spasial; Data Non Spasial (Atribut).

\section{Manusia}

Manusia merupakan inti elemen dari SIG karena manusia adalah perencana dan pengguna dari SIG. Pengguna SIG mempunyai tingkatan seperti pada sistem informasi lainnya, dari tingkat spesialis teknis yang mendesain dan mengelola sistem sampai pada pengguna yang menggunakan SIG untuk membantu pekerjaannya sehari-hari.

\section{Metode}

Metode yang digunakan dalam SIG akan berbeda untuk setiap permasalahan. SIG yang baik tergantung pada aspek desain dan aspek realnya.

\section{Mobile Computing}

Mobile Computing adalah sebuah paradigma baru dalam kemajuan teknologi yang dapat melakukan komunikasi dengan jaringan nirkabel sehingga user mampu melakukan perpindahan.[5]

\section{Jenis Mobile Computing [5] \\ 1) Laptop}

Merupakan komputer portabel, kecil dan dapat dibawa kemana saja dengan sangat mudah yang terintegrasi pada sebuah casing.Berat laptop berkisar dari 1 sampai 6 kilogram tergantung ukurannya, bahan dan spesifikasi.Sumber listrik berasal dari baterai atau $\mathrm{A} / \mathrm{C}$ adaptor yang dapat digunakan untuk mengisi ulang baterai dan untuk menyalakan laptop itu sendiri. Laptop kegunaannya sama dengan Komputer desktop, yang membedakannya hanya ukuran sehingga memudahkan pemakai untuk membawanya kemana-mana.

\section{2) Wearable Computer}

Biasanya disebut komputer yang dipakaikan di tubuh manusia.Contohnya adalah Computer Gletser Ridgeline W200.W200 ini terbuat dari paduan magnesium bertulang yang memaksimalkan kekuatan dan meminimalkan berat keseluruhan. Pada hanya 10,2 ons dan dibentuk pada kontur lengan, W200 yang mengkombinasikan fitur yang sama dari sebuah komputer standar dengan sebuah perangkat yang memberikan kenyamanan dan ergonomis pergelangan tangan instrumen aus. W200 ini memiliki sebuah 3.5 "layar warna dengan layar sentuh, keyboard backlit dan baterai hot swappable. Fungsi nirkabel dari W200 memastikan konektivitas berkelanjutan terlepas dari lokasi pengguna dengan plug and play Wi-Fi, Bluetooth dan modul GPS. Menggunakan CE Windows atau sistem operasi Linux, unit cepat dapat dikonfigurasi untuk mengakses sistem host remote melalui kabel terintegrasi atau antarmuka nirkabel. Operasi bebas dari tangan-W200 yang mengatasi keterbatasan fisik yang terkait dengan komputer genggam normal.Hal ini memungkinkan pengguna kebebasan penuh untuk melanjutkan kegiatan sehari-hari dengan menggunakan kedua tangan sedangkan komputer memiliki akses penuh pada setiap saat.Selain kompas elektronik, sistem juga mengintegrasikan fitur terbaru dan paling inovatif, seperti tilt dan perhitungan diam, yang memungkinkan penghematan baterai kritis ketika unit tidak digunakan.Kegunaan tangan-bebas dari W200 membuatnya kepentingan khusus untuk Layanan Darurat, Keamanan, Pertahanan, Gudang, Lapangan Logistik dan setiap wilayah di mana akses ke sejumlah besar informasi yang diperlukan.W200 punggung bukit itu bergabung baris gletser saat komputer kasar dikembangkan untuk pengumpulan data.

\section{3) PDA(Personal Digital Assistants)}

Sebuah alat elektronik yang berbasis komputer dan berbentuk kecil serta dapat dibawa kemana-mana. Menurut sepengetahuan saya PDA banyak digunakan sebagai pengorganisir pribadi pada awalnya, tetapi karena perkembangannya, kemudian bertambah banyak fungsi kegunaannya, seperti kalkulator, penunjuk jam dan waktu, permainan komputer, pengakses internet, penerima dan pengirim surat elektronik (e-mail), penerima radio, perekam video, dan pencatat memo. Selain dari itu dengan PDA (komputer saku) ini, kita dapat menggunakan buku alamat dan menyimpan alamat, membaca buku-e, menggunakan GPS dan masih banyak lagi fungsi yang lain. Bahkan versi PDA yang lebih canggih dapat digunakan sebagai telepon genggam, akses internet, intranet, atau extranet lewat Wi-Fi atau Jaringan Wireless.Salah satu ciri khas PDA yang paling utama adalah fasilitas layar sentuh.

\section{4) SmartPhone}

Ponsel yang menawarkan kemampuan canggih, boleh dikata kemampuannya menyerupai kemampuan PC (komputer). Umumnya suatu ponsel dikatakan sebagai smartphone bila dapat berjalan pada software operating system yang lengkap dan memiliki interface dan platform standar bagi pengembang aplikasi. Sementara itu ada yang mengatakan smartphone adalah ponsel sederhana dengan fitur canggih seperti kemampuan mengirim dan menerima email, menjelajah internet dan membaca ebook, built in full keyboard atau external USB keyboard, atau memiliki konektor VGA. Dengan kata lain, smartphone adalah miniatur komputer dengan kemampuan ponsel .

\section{E. Android}

Sebuah sistem operasi pada handphone yang bersifat terbuka dan berbasis pada sistem operasi Linux.Android bisa digunakan oleh setiap orang yang ingin menggunakannya pada perangkat mereka. Android menyediakan platform terbuka bagi para pengembang untuk menciptakan aplikasi mereka sendiri yang akan 
digunakan untuk bermacam peranti bergerak. Awalnya, Google Inc. membeli Android Inc., pendatang baru yang membuat peranti lunak untuk ponsel. Kemudian untuk mengembangkan Android, dibentuklah Open Handset Alliance, konsorsium dari 34 perusahaan peranti keras, peranti lunak, dan telekomunikasi, termasuk Google, HTC, Intel, Motorola, Qualcomm, T-Mobile, dan Nvidia. Pada saat perilisan perdana Android, 5 November 2007, Android bersama Open Handset Alliance menyatakan mendukung pengembangan standar terbuka pada perangkat seluler. Di lain pihak, Google merilis kodekode Android di bawah lisensi Apache, sebuah lisensi perangkat lunak dan standar terbuka perangkat seluler.[6].

\section{F. Tinjauan Studi}

Tabel 1. Penelitian Sebelumnya

\begin{tabular}{|c|c|c|}
\hline $\begin{array}{l}\text { Judul dan } \\
\text { Pengarang }\end{array}$ & Pembahasan & Hasil \\
\hline $\begin{array}{lr}\text { Sistem } & \text { Informasi } \\
\text { Geografis } & \\
\text { Kesesuaian } & \text { Lahan } \\
\text { Tanaman } & \text { Debu } \\
\text { Berbasis } & \text { Android } \\
\text { (Marwoto, 2007) }\end{array}$ & $\begin{array}{l}\text { Membahas tentang } \\
\text { otomatisasi evaluasi } \\
\text { kesesuain lahan untuk } \\
\text { potemsi deteksi } \\
\text { pengembangan areal } \\
\text { tebu dengan } \\
\text { memadukan teknologi } \\
\text { penginderaan jauh } \\
\begin{array}{l}\text { yang berbasis web } \\
\text { dan android. }\end{array}\end{array}$ & $\begin{array}{l}\text { Penelitian ini } \\
\text { menghasilkan } \\
\text { kesesuaian lahan } \\
\text { tanam tebu pada } \\
\text { kabupaten } \\
\text { Marueke Papua. }\end{array}$ \\
\hline $\begin{array}{l}\text { Analisis Indeks } \\
\text { Kesesuaian Lahan } \\
\text { Tanaman Padi dan } \\
\text { Jagung } \\
\text { Menggunakan } \\
\text { Sistem Informasi } \\
\text { Geografis dan Multi } \\
\text { Criteria Decision } \\
\text { Making (Iin Kusuma } \\
\text { Wardani, 2010) }\end{array}$ & 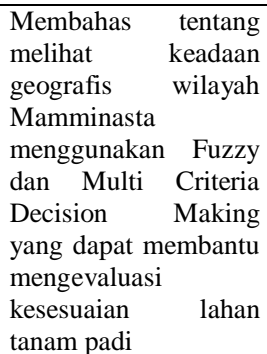 & $\begin{array}{l}\text { Hasil } r \text { dari } \\
\text { penelitian ini } \\
\text { berupa aplikasi } \\
\text { GIS dengan Peta } \\
\text { Tematik sehingga } \\
\text { memudahkan } \\
\text { pencarian lokasi } \\
\text { lahan tanam padi } \\
\text { dan jagung pada } \\
\text { kawasan } \\
\text { Mamminasta }\end{array}$ \\
\hline 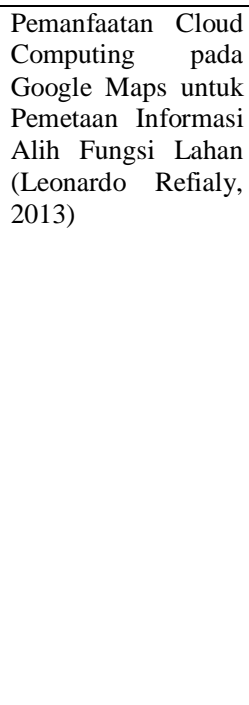 & $\begin{array}{l}\text { Membahas tentang } \\
\text { pemetaan informasi } \\
\text { alih fungsi lahan } \\
\text { beserta indicator- } \\
\text { indkator melalui suatu } \\
\text { peta digital } \\
\text { menggunakan Goggle } \\
\text { MAP API dan } \\
\text { Teknologi ASP.NET } \\
\text { dengan layanan cloud } \\
\text { computing. }\end{array}$ & $\begin{array}{l}\text { Hasil dari } \\
\text { penelitian } \\
\text { adalah mampu } \\
\text { menyederhanakan } \\
\text { pengelolaan } \\
\text { layanan TI, dan } \\
\text { mempercepat } \\
\text { penghantaran } \\
\text { layanan } \\
\text { informasi dan } \\
\text { pengetahuan } \\
\text { pertanian kepada } \\
\text { penggunanya baik } \\
\text { itu petani maupun } \\
\text { pemerintah } \\
\text { setempat, sehingga } \\
\text { dapat } \\
\text { meningkatkan } \\
\text { produktifitas di } \\
\text { sektor petanian } \\
\text { Minahasa } \\
\text { Tenggara. }\end{array}$ \\
\hline
\end{tabular}

\section{Analisis dan Perancangan}

\section{A. Analisis Kebutuhan Fungsional}

1) Sistem dapat memberikan informasi apakah lahan tersebut layak untuk ditanami singkong berdasarkan paramater ( Hasil panen, Temperatur cuaca, ketersediaan air, ketersediaan oksigen, media perakaran, gambut/ Jenis lahan, Retensi hara, bahaya banjir, penyiapan lahan).

2) Sistem dapat mempresentasikan lokasi menggunakan GIS.

3) Memudahkan calon investor dalam mengakses informasi kesesuaian lahan tanam singkong di Provinsi Lampung.

4) Memudah kan admin untuk melakukan pembaharuan data menggunakan Web Technology.

\section{B. Analisis Kebutuhan Non Fungsional}

1) Operasional User menjadi lebih mudah memperoleh informasi mengenai apakah suatu wilayah tersebut layak atau tidak untuk penanaman singkong

2) Performa

Sistem dapat diakses melaui web browser dan android

3) Keamanan

$\checkmark$ Dibuatkan suatu user login untuk akses sistem sehingga sistem mengatur hak akses dalam penggunaan sistem.

$\checkmark$ Menggunakan .htaccess untuk security sehingga url yang di tampilkan pada browser bukan merupakan url sesungguhnya.

\section{Pengambilan Data}

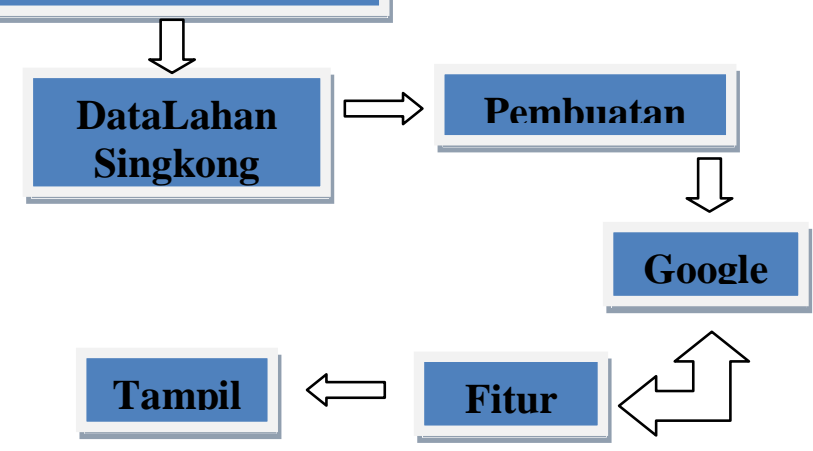

Gambar 1. Diagram Alur Program

\section{Use Case Diagram}

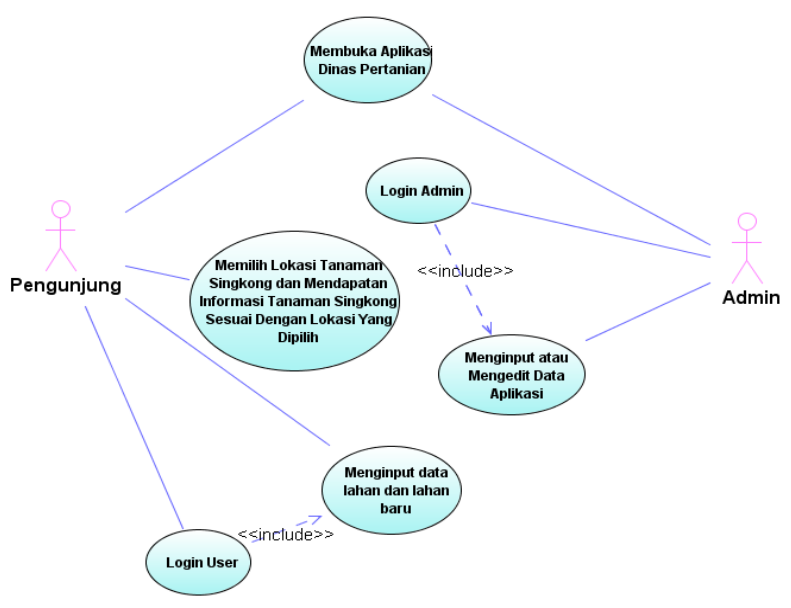


Gambar 2. Use Case Diagr Gambar 2.Use Case Diagram

\section{Implementasi dan Pembahasan}

Menggunakan sistem merupakan tahap meletakkan sistem supaya siap dioperasikan.Tahap penggunaan sistem ini dilakukan setelah sistem selesai dievaluasi, kemudian peneliti melaksanakan pelatihan terhadap personil dengan memberi pengertian dan pengetahuan yang cukup tentang sistem informasi, posisi dan tugas setiap fungsi. Pelatihan ini untuk personil yang mengoperasikan sistem, yaitu admin dan user. Hal ini dimaksudkan agar user memahami prosedur kerja sistem, dapat mengurangi kesalahan-kesalahan yang timbul yang dapat menghambat kelancaran operasional perusahaan, sehingga penggunaan sistem informasi sukses. Sistem yang peneliti buat ini diharapkan tidak adanya lagi keterlambatan pengentrian data dan pembuatan laporan. Sistem baru ini dirasakan lebih baik digunakan dibanding dengan sistem yang lama karena proses pengerjaan inputan data dan pembuatan laporan tidak memakan waktu yang lama. Berikut program dari sistem yang siap untuk digunakan:

\section{A. Login}

Login password merupakan tampilan pertama pada saat program dijalankan.Tampilan form ini, berfungsi untuk keamanan data di mana pengguna diminta untuk meng-inputkan password yang telah ditentukan sebelumnya. Adapun tampilan form login dapat dilihat pada gambar berikut :

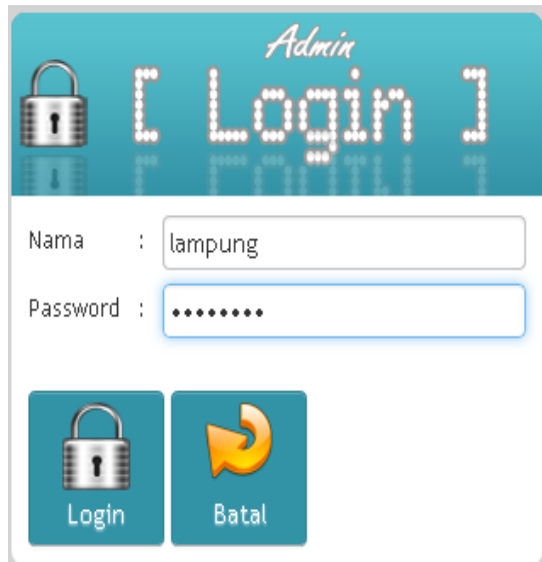

Gambar 3. Form Login

\section{B. Menu Utama}

Form ini merupakan menu utama dalam aplikasi karena berfungsi untuk mengakses menu-menu lainnya yang terdapat pada aplikasi. Tampilan menu utama program dapat di lihat pada gambar berikut :

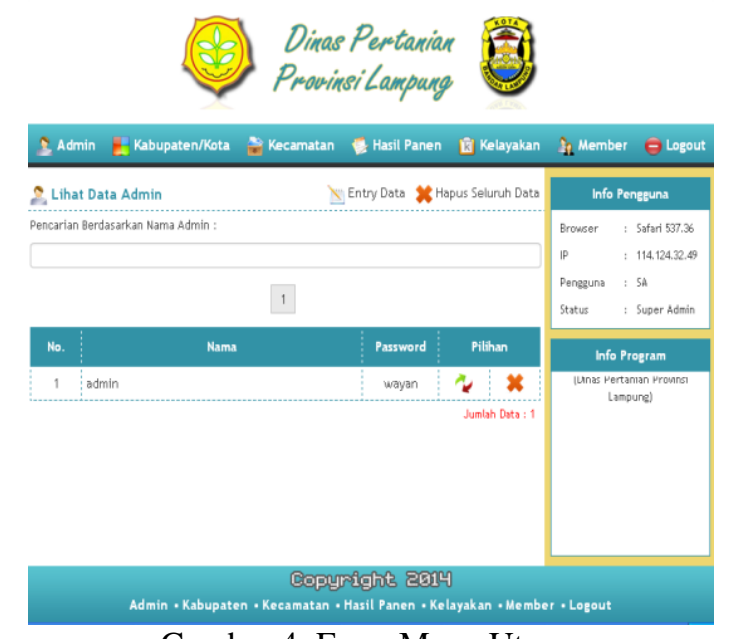

Gambar 4. Form Menu Utama

\section{Kelayakan Hasil Panen}

Halaman kelayakan hasil panen merupakan tampilan form yang digunakan untuk melihat apakah dalam suatu wilayah tersebut layak atau tidak ditanami singkong. Tampilan form kelayakan hasil panen dapat di lihat pada gambar berikut :
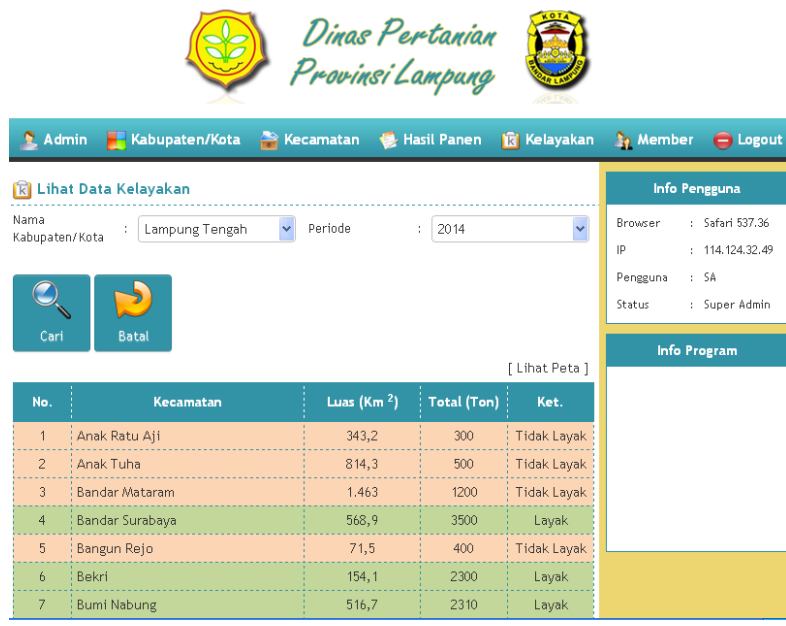

Gambar 5. Kelayakan Hasil Panen

\section{Halaman Tampil Peta}

Halaman tampil peta digunakan untuk mencari titik koordinat dari suatu wilayah, tampilan peta diambil dari google map, adapun tampilan tampil peta dapat dilihat pada gambar berikut :

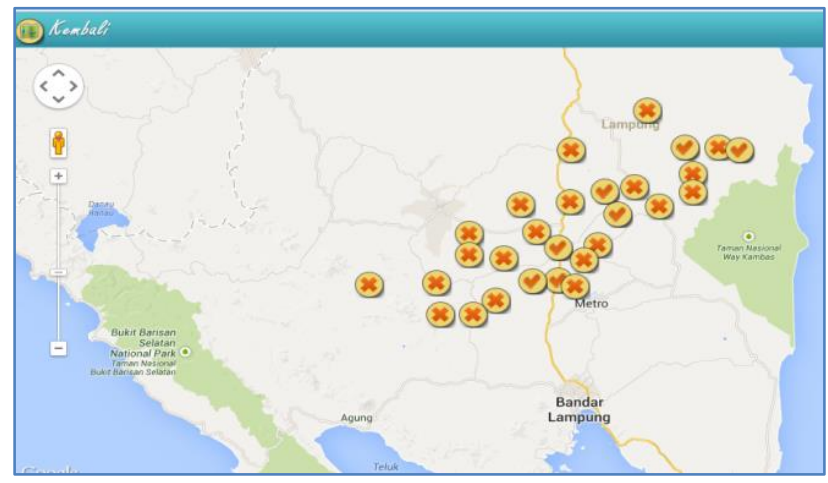

Gambar 6. Halaman Tampilan Peta 


\section{E. Pengujian Hasil Kesesuain Lahan Tanam}

Dari data yang sudah dimasukkan berdasarkan data dari Dinas Pertanian Provinis Lampung didapatkan data hasil panen sebagai berikut :

Tabel 2. Hasil Tanam Singkong Berdasarkan Kecamatan

\begin{tabular}{|l|c|r|r|r|}
\hline \multirow{2}{*}{ Nama Kecamatan } & \multicolumn{3}{|c|}{ Tahun Hasil Panen (Ton) } & \multirow{2}{*}{ Total } \\
\cline { 2 - 4 } & 2012 & 2013 & \multicolumn{1}{c|}{2014} & \\
\hline Tanjung Bintang & 1000 & 1500 & 1200 & 3700 \\
\hline Tanjung Sari & 1500 & 1000 & 1200 & 3700 \\
\hline Sido Mulyo & 2000 & 1260 & 1340 & 4600 \\
\hline Kota Agung & 1250 & 2000 & 2100 & 5350 \\
\hline Terbanggi Besar & 2200 & 1250 & 2000 & 5450 \\
\hline
\end{tabular}

Berdasarkan data dan aplikasi yang sudah disimulasikan, didapatkan wilayah lampung selama tiga tahun terakhir (2012-2014) yang paling layak ditanami singkong berdasarkan hasil panen dapat dilihat pada gambar 6 .

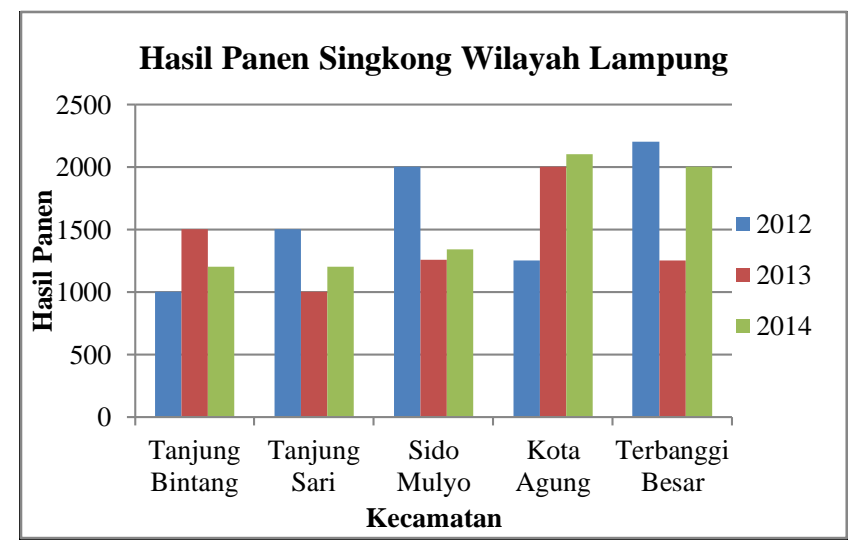

Gambar 6. Grafik Hasil Panen Singkong

\section{Simpulan dan Saran}

\section{A. Simpulan}

Berdasarkan hasil dan pembahasan maka dapat diambil kesimpulan bahwa aplikasi kelayakan lahan tanam singkong berbasis android mobile diterapkan dengan menggunakan sistem informasi geografis, dengan menggunakan aplikasi berbasis web dan android mobile. Diharapkan dengan adanya aplikasi ini dapat membantu masyarakat provinsi lampung dan investor dalam memilih kelayakan lahan tanaman singkong.

\section{B. Saran}

Perlu dilakukan penelitian selanjutnya untuk kelayakan tanaman singkong tidak hanya diprovinsi lampung saja, akan tetapi dapat diterapkan diseluruh pulau yang ada di Indonesia.

\section{Daftar Pustaka}

[1] A.Taufiq Hidayatullah, (2008). Aplikasi Web Database menggunakan Adobe Dreamweaver \&Pemrograman $P H P+M y S Q L$. Andi, Yogyakarta.

[2] Anhar, (2010).Membuat Aplikasi DataBase MySQL. Yogyakarta: Gava Media.

[3] Hakim A, Muhammad, (2007) "Makalah Studi dan Implementasi Sistem Informasi Geografis Pencarian Lahan Tamanan Pisang”, Teknik Informatika ITB.

[4] Prahasta Eddy, (2003). Sistem Informasi Geografis : ArcView Lanjut. Andi, Yogyakarta.

[5] Ani Puji Rahayu, (2010) "Makalah Penerapan Aplikasi Mobile Computing Untuk Mendeteksi Kepribadian Manusia Berdasarkan Wajah”, Teknik Informatika ITB.

[6] Safaat Nasrudin, (2012). Pemrograman Aplikasi Mobile Smartphone dan Tablet PC Berbasis Android

[7] Marwoto (2007) Sistem Informasi Geografis Kesesuaian Lahan Tanaman Debu Berbasis Android

[8] Iin Kusuma Wardani (2010) Analisis Indeks Kesesuaian Lahan Tanaman Padi dan Jagung Menggunakan Sistem Informasi Geografis dan Multi Criteria Decision Making

[9] Leonardo Refialy (2013) Pemanfaatan Cloud Computing pada Google Maps untuk Pemetaan Informasi Alih Fungsi Lahan 